\title{
Visual Information for digital inclusion process in hybrid libraries and librarians' action
}

\author{
Rafaela Carolina da Silva* \\ Maria José Vicentini Jorente \\ Rosângela Formentini Caldas \\ Natalia Nakano
}

Artículo recibido:

24 de mayo de 2016

Artículo aceptado:

14 de noviembre de 2016

\begin{abstract}
The set of actions and cultural conditions of a society produce information in such a way to act directly on the development and use of services and goods by this society. Digital inclusion and the use of images is encouraged as converging languages within hybrid libraries. We aimed to study attractive resources provided by visual language in social and digital inclusion processes. Therefore, we carried out a literature review on the syntax of visual languages. As a result, a Guide for Librarians was constructed. We concluded that understanding and using images serve as a convergence for those who experience them.
\end{abstract}

* Universidade Estadual Júlio de Mesquita Filho, São Paulo State, Brasil. rafaelacarolinasilva@gmail.com mjjorente@yahoo.com.br rcaldas@marilia.unesp.br natinakano@gmail.com

INVESTIGACIÓN BIBLIOTECOLÓGICA, vol. 32, núm. 76, julio/septiembre, 2018, México, ISSN: 2448-8321 pp. 79-96 
Keywords: Information and Technology; Visual Information; Visual Languages. Digital Inclusion.

La información visual para el proceso de inclusión digital en bibliotecas híbridas

Rafaela Carolina-da-Silva, Maria-José Vicentini-Jorente, Rosângela Formentini-Caldas and Natalia Nakano

\section{RESUMEN}

El conjunto de acciones y condiciones culturales de una sociedad produce información, de tal manera que actúa directamente sobre el desarrollo, uso de servicios y bienes por parte de dicha sociedad. Se fomenta la inclusión digital y el uso de imágenes como idiomas convergentes dentro de las bibliotecas híbridas. Apuntamos a estudiar los recursos atractivos proporcionados por el lenguaje visual en los procesos de inclusión social y digital. Por lo tanto, realizamos una revisión de la literatura sobre la sintaxis de los lenguajes visuales. Como resultado, se construyó una guía para bibliotecarios. Concluimos que la comprensión y el uso de imágenes sirven como convergencia para quienes experimentan dichos lenguajes.

Palabras clave: Información y Tecnología; Información Visual; Lenguajes Visuales; Inclusión Digital.

\section{INTRODUCTION}

$\mathrm{T}$

The liberal trend of the Enlightment in the eighteenth century promoted a new idea of education focused on human beings and stimulated proletariat movements to pressure society to conquer benefits such as the popularization of education. Generally, we can say that the philosophical pedagogy of the Enlightment marked the western history, as principles of liberty and equality were also present at French Revolution (Pereira, 2013: 10).

The Encyclopedia, or Systematic Dictionary of the Sciences, Arts, and Crafts was the main instrument that publicized the thought of the Enlightment movement; it also replaced the faith on the Catholic Church by the faith on the 
scientific knowledge. In the beginning, part of the encyclopedia remained secret, but the Encyclopedist movement allowed its popularization.

The Enlightment resulted in an international development of scientific production and education of society in the nineteenth century. In this context, the vision of library techniques and formats changed because of the industrial intervention.

However, technological transformations taking place at that historical moment did not cause users the impact at first. In this perspective, the historical conjuncture of Second World War, the conflicts among development, populism and labor issues became the foundation of social, political and cultural relations.

Literacy and basic education of children and adults were stimulated in technical courses, establishing the grounds for the educational model we have today: elementary school, high school and higher education (Simili, 2008). Thus, after the Second World War, the world changed, and in consequence, the work of librarians also changed and incorporated different modes of language and thoughts - texts, images, sounds and voices in a multimedia environment, with digitization allowing the organization of information flow (Santaella, 2001: 393).

This convergence of languages was possible because of reading in different formats that allow the contact with digital languages, i.e., concepts that simulate, through computing, products and services in the real world. In this context, the librarians are part of this scenario in which access to information involves not only practice, but also the individual being favored by such practice in a way to construct the collective of the institution through converging languages.

Thus, we witness a convergence of languages and media. The study of visual language syntax, such as in verbal language, determines the semantic results achieved through the visual communication process: instead of the subject-verb-predicative structure of the verbal language, the visual language organize its parts according to human perception.

In this way, by uniting two or more languages, such as written, sound, visual and audiovisual, what we have is named converging languages (or hybrid languages), which are characterized as visual languages, but also comprise other types of communication such as the sound, essential to human perception and their interaction is achieved through attraction and grouping relations.

We highlight that in the Gestalt principles (Berlin School of experimental psychology) the psychophysiological relations of the brain are spontaneous and sharpened according to attraction and dispersion of the images relations. Therefore, human beings receive and express visual messages in different levels: representational, abstract and symbolic. 
The human eye tends, from generalizations, to make individual records of the elements with similar characteristics, intellectually forming concepts (Arnheim, 2005). As a consequence, the semantic or meaning of a language emerges from the moment the subject uses a set of signs to express himself.

It is, therefore, necessary that human beings know how to decode a language in order to interpret it, and then generate meaning. These meanings, when applied, will construct knowledge, generating new information needs for the subjects.

Visual language, when worked out in such a way to allow the convergence of traditional means, focused on physical spaces as well as digital ones, mediated through electronic or digital, is acting on the so-called hybrid spaces. Thus, hybrid library settings converge different types of languages (visual, sound and textual) as well as traditional and digital technologies, which turn them into hybrid, dynamic spaces, more accessible to the community.

In this context, the purpose of this paper is to describe the syntax of visual language and its applicability in hybrid library settings, observing the context of how visual language can provide more attractive and dynamic ways to visualize the resources of information centers, and consequently contribute with digital inclusion in libraries.

The approach was qualitative, exploratory and explanatory. The method used was the bibliographical research. The research universe sought to focus on the transformation processes of informational supports and the formal and conceptual characteristics of the messages provided by visual information. Subsequently, we propose a semantic application of this study through the development of a guide for professionals working in the library environment.

The purpose was to guide professionals to choose visual structures to attract the users' interest to attend the library. Given that, we can argue that cognitive and human changes from new social demands made imperative that information professionals and cultural agents understand languages that interact with the library.

Hence, in order to have the services offered by hybrid libraries publicized and implanted in this new paradigm, the participation of the information professional, analog and digital technologies and languages is necessary. Thus, segmentation and institutional participation are part of decoding and coding of information by users and information professionals.

\section{VisuAL LANGUAGE SYNTAX}

Unlike verbal language, visual language presupposes visual intelligence with visual literacy, due to the vision system of the human eye. Walter Benjamin, 
already in 1936, when he wrote The work of art in the age of mechanical reproduction stated that "Pictorial language has not yet matured because our eyes have not yet adjusted to it. There is as yet insufficient respect for, insufficient cult of, what it expresses" (Benjamin, 2008).

Most part of language explorations start from the idea of space as the perceptual field of an observer. The comprehension of the discourse of these images needs help and translations into the natural verbal language, which is better known, due to the little education that western society has of visual language.

The notion of image for Joly (2007) is related to visual representations whether they are painting, pictorial ornamentation, decorative illustration, drawings, pictures, movies, videos, photos and compound images.

The image, as part of a language system to be interpreted by humans, has contents expressed by symbols decoded by the receiver of the message. Therefore, "to see" means to create mental images. Mental images are the result of schemes based on written syntax and visual language. They mean, therefore, the capacity of reading and writing of visual language so that other people may repeat the process. Knowing how to interpret a language is different from the natural speech process. Humans are born with a tongue, but the development of language evolves in a broader context, which derives from learning and decoding of words.

In the context of visual languages, tonality determines what human eyes see. Thus, the brighter the light in a color, the clearer it will be; on the other hand, the lesser the light, the darker the color, and the total absence of light defines the color black.

What light reveals, in addition to human perception, identifies the elements of an image: dots, lines, color, shape, direction, texture, scale, dimension and movement. Images, both photographic and digital, are essentially composed by the primary colors blue, red and green modified with the presence of light.

In turn, the light, composed by these three colors, is the basis for forming other colors. The vanishing point, or intersection of a set of parallel lines in space on the image view, is the spot where individuals unconsciously, immediately look when they observe a picture and thus is the key factor of an image.

Considering that, in western culture, people learn how to read written texts supported by paper or electronic devices upside down and left to right since childhood, it is possible to adjust the visual elements in order of importance. Thus, beyond the dimension and vanishing point, another important technique is the use of negative and positive points: the positive element is what appeals to the eye in the visual experience, and the negative element is everything else presented in a more passive manner (Dondis, 2003). 
When individuals see an image, they can understand the general meaning of information and when they interpret the content of the received message, they create new information and disseminate it (principle of human communication). Consequently, what makes an image attractive or not to the eyes of the seer is the way how the image is seen and displayed by an information institution.

In this sense, the use of contrasts appeals the user's attention because it stimulates them to seek for a visual balance. Therefore, the information professional must understand the principles of balance between contrast and harmony, or between simple and complex so that this professional can implement visual languages in hybrid libraries under this perspective to attract the community.

We have observed, in this study, that humans seek to balance what they observe, but in the harmonizing process they are attracted to contrast, i.e., contrast is necessary to reach balance. Hence, what the eyes see defines what the brain will signify.

\section{VisUAL LANGUAGES AND DIGITAL INCLUSION: A HYBRID CONTEXT}

A society's culture determines the development of its goods and services. "An important assertion of theories on post-industrialism is that people, in addition to being involved in different activities, also take over new positions in the occupational structure" (Castells, 2001: 238).

Thus, the library as a social institution must seek new positions in the occupational structure of society in order to be reintroduced in this new context. These positions comprise gathering all sectors of intelligent communication, that is, Information and Communication Technologies (ICT).

In parallel to traditional libraries, which open room for information access, a hybrid library defines behavioral/mental parameters that allow greater cognitive interaction between agents and information professionals. Thus, the environment of a collaborative hybrid library provides flexibility of the offered products and services (Pinfield et al., 1998), as the organizational structure proposes a variety of languages that comprehend the hybrid spaces.

Thus, the basic requirements of a hybrid library are: providing services for research, location, requisition, shipping/delivery and use of resources; the provision of services must be consistent for both local and remote resources, regardless of the formats; the organizational structure must be flexible to stimulate the development of new systems when necessary; the systems must be based on international standards to increase volume and traffic of resources 
(Russel et al., 1999). In addition, we propose that images, visual resources and visual literacy instruments must be part of the library collections, resources and activities.

The potential of the image in the process of absorbing information in hybrid libraries parts from the assumption that the librarian, incorporating to his/her knowledge, the use of visual elements, contributes to digital literacy. To do so, such representations must relate to the type of audience and the way the content is viewed.

Therefore, it is essential information professionals learn about visual languages so that the images and the sounds act in a synthetic and immediate way on people's psychological, being more direct in the creation of knowledge. In the digital context, information can be constructed or deconstructed at any moment, without the limitation of space and time. The informational flow interconnects the generator (librarian) and the receiver (library users) of the information more quickly and broadly.

Thus, the hybrid library environment should encompass not only a space for studying, but also a dynamic, convenient space, where different types of people can be together. Thinking in a friendly, flexible and warm environment facilitates the learning process, as diversification between quality and quantity, among visual, sound and written languages can help in the interpretation of something that is proposed to the teaching, since they are part of the human experience.

In the interactive and supportive environment of hybrid libraries, individuals are comfortable to create knowledge culture, involving the information system as a whole, constructing a relationship of data, information and knowledge multiculturalism. The concept of hybrid libraries should then be present in the promotion of information in public libraries both in analog context, in a way to think the internal and external physical environment of the library, and its digital ambience.

Digital inclusion is introduced in this scenario in actions to promote access to electronic sources of information. In this perspective, related to visual languages, digital inclusion demands understanding different media and, at the same time, different languages that converge onto different supports.

The library is, therefore, "an organism that converges its objectives in the users' sake, towards their information needs and peculiarities" (Bernardino and Suaiden, 2011: 34-35) in order to provide information access to all, i.e., to democratize information to bring up conscious citizens. "A hybrid library [...] integrates both the traditional libraries' functions as well as digital libraries. Unlike fully digital libraries, a hybrid library augments the functions of a traditional library rather than replacing” (Prakasan et al., 2000: 293). 
Digital inclusion parts from digital literacy or from the ability to understand, assess and use information from different sources (Bruce, 2003). The literacy process occurs not only from the perspective of traditional and digital technologies, but also from the production and construction of knowledge through converging languages and information access.

Information units, through their objectives and goals, "find, understand, disseminate and use knowledge generated at work in order to value both the institution and education" (Caldas, 2013: 241). In this context, human abilities start to be developed, along with the information units' working tools, to create efficient processes for information dissemination.

Libraries have gone through four phases of development in relation to social changes: traditional libraries, automated libraries, hybrid libraries and digital libraries (Prakasan et al., 2000). The hybrid library is the bridge, which connects traditional and digital library, using information sources in different formats and in remote or local places in an integrated way.

The concept of hybrid information environment "should go beyond the limits of conventional strategy, try to visualize the future and create mechanisms to achieve the purpose of helping users with their needs and expectations" (Stuart and Varvakis, 2002: 46). Hence, hybrid information environments must establish a structure of continuous improvement with quality information services which is thought and re-thought according to the actions programmed in the communities they serve.

In the same line, on the five lines of action of a librarian's reference service (Dias, 1990), we have observed that digital media, as intuitive interfaces of digital images, are means of digital inclusion in hybrid libraries. These services, named "extension services", go beyond the exclusive setting of the library and must be extended outside the institution's environment.

Thus, in the search for interaction between visual languages in digital platforms and the work of library professional, this paper aimed to relate the lines of action of a reference service with the five laws of Ranganathan known as "Five Laws of Library Science", as shown in figure 1 in the context of hybrid libraries:

\begin{tabular}{|l|l|l|}
\hline \multicolumn{1}{|c|}{ Lines of action } & \multicolumn{1}{|c|}{ Laws of Library Science } & \multicolumn{1}{|c|}{$\begin{array}{c}\text { Interactions between visual lan- } \\
\text { guages and hybrid institutions }\end{array}$} \\
\hline Reference service & Books are for use & $\begin{array}{l}\text { Librarian's role and access to } \\
\text { technology }\end{array}$ \\
\hline User's education & Every book its reader & $\begin{array}{l}\text { Users and librarian's training in } \\
\text { the use of media, technologies } \\
\text { and languages. }\end{array}$ \\
\hline
\end{tabular}




\begin{tabular}{|l|l|l|}
\hline $\begin{array}{l}\text { Information Notice and } \\
\text { Dissemination }\end{array}$ & Every reader his/her book & Promotion of information access \\
\hline $\begin{array}{l}\text { Visual Communication/ populari- } \\
\text { zation of library }\end{array}$ & Save the time of the reader & $\begin{array}{l}\text { Policies for use and innovation } \\
\text { of services and products offered } \\
\text { by library }\end{array}$ \\
\hline Management/supervision & The library is a growing organism & User-library interaction \\
\hline
\end{tabular}

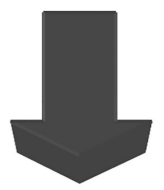

ADAPTABILITY IN HYBRID LIBRARIES

Figure 1. The rol of librarians with converging languages to promete adaptability in the hybrid context Source: By authors

In the context of hybrid libraries, the use of technologies benefit librarian communities which, in turn, benefit the new social environments, as from the point of view of the library practice, they must be prepared to face future challenges. In this sense, as Crawford and Gorman (1995) point out, in their re-examination of Ranganathan's Laws, the libraries, face a technological society, must take into account five new laws of librarianship, namely: a) Libraries serve humanity; b) Respect all form by which knowledge is disseminated; c) Use technological intelligence to improve service; $d$ ) Protect free access to knowledge; e) Honor past and create future (Crawford and Gorman, 1995).

Therefore, concerning Reference Service, it should value the service via human interaction, in which the professional seeks to obtain most information possible from the user to guide them with expertise. The law books are for use, but not only books - in libraries, cultural agents should also strategically take advantages of all resources in informational support, such as blogs, social media, exhibitions of artists, poets, musicians, teachers, users, banners, mobiles on library walls and ceilings, posters of new acquisitions and events that will take place in the institution; banners that draw users' attention on the use of the information they receive; campaigns to motivate reading, and the proper return of borrowed material. The interaction between visual languages and hybrid environments occurs through the librarian's role as intermediate in information technology access to both digital and analog formats.

User's Education regards guidance, instruction and training of users and librarians through a permanent system which connects these individuals and information retrieval means. The law every book its reader concerns not only for books, but any resource in information support available at hybrid 
libraries for their users. The interaction between visual languages and hybrid environments occurs from the training for customers and information professionals, as well as from the use of digital visual information (courses, workshops or other ways to teach people how to access and work with available information in digital environments, as well as data collection techniques: interview with customers and empirical tests of digital information usage.

Information Notice and Dissemination contributes with the users' guidance in relation to ways to retrieve information. The law every reader his/her book also refers to other kind of formats used in the library. The interaction between visual languages and hybrid libraries is in library's duty to guarantee access to knowledge, educating critical individuals who think before receiving information.

Visual communication/popularization of library relates to the informative publications structured within the library environment in such a way to save the time of the reader. Thus, the interaction between visual languages and hybrid organization reflects the policies of use and updates in the information environment, so that users do not need to go to the library to ask questions such as the working hours of the library, for example.

In management/supervision, the emphasis is in the management processes, the institution policies, planning, organization, methodologies and assessment of the library service, considering that The library is a growing organism. The interaction between visual languages and hybrids environments derives from resources available for users to give opinions and suggestions regarding the development of the library collection.

In this way, if we focus, for example, in reference service, we have Ranganathan's law books are for use. This sentence emphasizes the librarian's role as the bridge between information technologies in digital and analogical contexts and the access to them.

From this perspective, what is at stake is information processing in order to enable users' social inclusion. Hybrid libraries, therefore, encourage this process, interconnecting technologies, contexts and people.

Lyon Declaration (IFLA, 2014) highlights the social role of libraries which, supported by technologies, provide increased access to information and knowledge. The Declaration takes into account the social role of libraries and librarians in providing information for the development of citizenship by providing "information on basic rights, public services, the environment, health, education, Job opportunities and public spending that supports local communities and individuals to guide their own development" (IFLA, 2014: 2). 
Likewise, by comparing figure 1 with Librarian 2.0 Manifesto (Johannessen, 2006), we realize that this figure characterizes as an extension of this manifesto as it relates the practice of library science, the technology development and the visual languages to the intellectual development process.

The manifesto compares Web 2.0 (or collaborative web) and the informational professional activities. The librarians, according to this document, recognize their importance as information professionals and also accept the technological transformations that the modern world imposes on individuals that need to adapt to them.

In this scenario, what could explain the absence of digital inclusion in libraries are the barriers imposed to ICT implementation in these environments, result of a conservative thought, which benefits from the ignorance of these languages reflected in the conformist librarian. On the other hand, as new forms of knowledge generation and sharing gain strength in society, the need to implement new inclusion policies is encouraged in such a way that new social paradigms become an ideal for social survival.

Thus, a more flexible, decentralized, cooperative, innovative work, focused on the user, develops the basis for intellectual formation in social networks. We, therefore, infer that the library's environment begins to provide their users' digital inclusion.

\section{Methodological Procedures}

The approach of the study was qualitative in face of the verified phenomena, focusing on the process and the attribution of meanings, with a more detailed understanding of these meanings (Taylor et al., 2015).

The research, regarding its objective, was characterized as exploratory and explanatory. Such characteristics lie in the description of the development of syntax in visual languages, explaining this phenomenon together with the experience of digital inclusion for hybrid libraries.

Thus, the primary objective identified factors that determine or contribute to the occurrence of visual languages in digital inclusion in the hybridization environment. It is believed that studying and identifying the factors that determine or contribute to the occurrence of phenomena is the type that deepens the knowledge of reality, because it explains the reason why things are the way they are.

The method used was the bibliographical research, with the intention of deepening the theoretical and methodological foundation regarding the processes of transformation of informational supports provided by visual information. The semantic application of this study provided the development of a guide for librarians. 
Considering that the converging media, i.e., the ICT, are hybrid languages present in the lives of librarians and information users, this paper aimed to contribute in the processes of understanding these languages. We created two Communication Guides to Librarians, represented in the figure 2 and in the table 1 . The figure 2 shows the actions librarians should follow to implement visual languages in their praxis, as shown below:

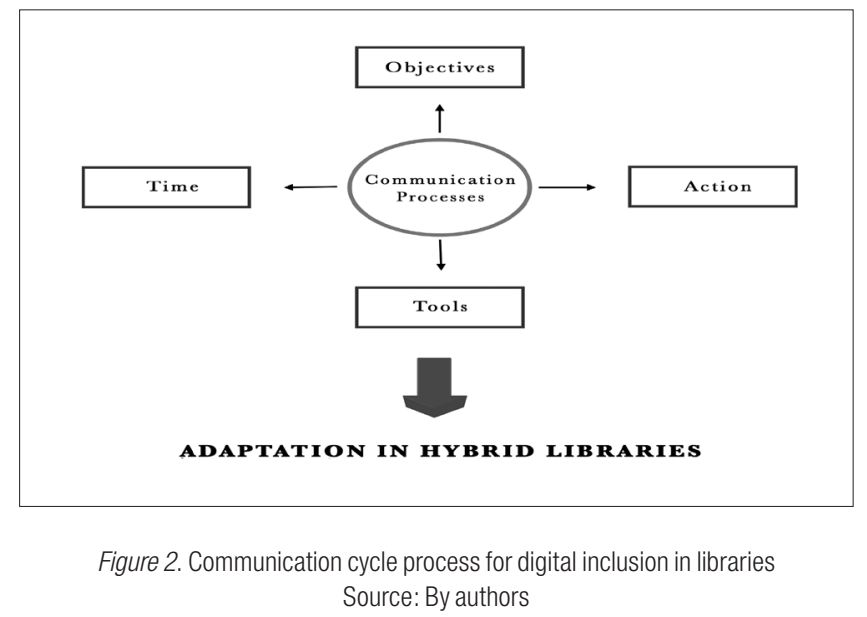

Firstly, we propose that the information professional should define the subject to be worked. The objectives and actions of communication, the target audience, and the types of communication tools and the time to carry out the actions are aspects to be considered after the subject definition.

The communication process must have a definite period carried out, starting by the project planning and finishing with the feedback of activities. The objectives related to dissemination, innovation and use of converging languages, having the analog and digital communication technologies as action tools, such as banners, mobiles and social media.

To exemplify, if the planning subject is to provide services that meet the new social demands of users in a hybrid academic library, the librarian should:

1) Propose to innovate services in order to transform the library into a place that fosters digital inclusion. 
2) Encourage communication actions made possible by converging languages and media.

3) Use both analog and digital technologies.

4) Define a relevant institutional period to execute those actions.

Regarding analog technologies, exhibitions, posters, banners and mobiles spread on the walls of the library are high impact tools in users' perceptions. As for digital technology, social media, websites and electronic billboards are options.

The period for carrying out campaigns to implement services must occur in such a way to reach as many users as possible. In the example above, we chose the academic year ${ }^{1}$ so that freshmen could acknowledge the services offered by the library; in the second semester when these students (now library users) come back from vacation, and the end of the second semester to close the communication process cycle.

As for labor division and the actions to be carried out by the information professionals, the table 1 divides the professionals' activities in four parts: relationship with external environment, participation in events, involvement of all, and relationship with external public.

\begin{tabular}{|l|l|}
\hline \multicolumn{1}{|c|}{ Actions to be developed } & \multicolumn{1}{c|}{ Professional information } \\
\hline $\begin{array}{l}\text { Relationship with the external environment (media, } \\
\text { social media, people in general) }\end{array}$ & $\begin{array}{l}\text { - Administration personnel, the assistant librarian } \\
\text { and reference librarian who are always in contact } \\
\text { with social media technologies. } \\
\text { - Organization staff, who know the availability of } \\
\text { the collection and the best spots to place posters } \\
\text { and mobiles. } \\
\text { - Standard librarian and reference librarian, who } \\
\text { better know the users' needs and demands. }\end{array}$ \\
\hline Participation in events & $\begin{array}{l}\text {-Director and reference librarian, who can better } \\
\text { explain the projects to participants. }\end{array}$ \\
\hline
\end{tabular}

1 The academic year in Brazil is divided into two semesters. Students have winter vacations in July, and summer vacation in December and January. 


\begin{tabular}{|c|c|}
\hline Involvement of all & $\begin{array}{l}\text { The Project should involve the participation of all } \\
\text { departments of the library, as well as its users. Thus: } \\
\text { — The administrative sector, assistant librarian } \\
\text { and reference librarian may publicize the project } \\
\text { electronically. } \\
\text { — The organization staff may take the communica- } \\
\text { tion tools available in the library and also plan how to } \\
\text { publicize those tools. } \\
\text { — The reference staff may be responsible for help } \\
\text { users with their doubts about the publicized content. } \\
\text { — The directory staff may be responsible for the } \\
\text { financial costs. } \\
\text { — The front desk staff may assist users with doubts } \\
\text { about communication resources. } \\
\text { — The marketing may take care of resources } \\
\text { outside the environment of the library. } \\
\text { — The Director should develop the scientific struc- } \\
\text { ture of the project and assess its applicability. } \\
\text { — The cleaning staff should keep the structure } \\
\text { clean and organized. } \\
\text { — The users shall then assess the benefits and } \\
\text { problems of the project. }\end{array}$ \\
\hline Relationship with library staff & $\begin{array}{l}\text { The internal public should be involved in the execu- } \\
\text { tion of all tasks, so the participation of all is impor- } \\
\text { tant to carry out the task. Therefore, the distribution } \\
\text { of tasks is a form of organization, which does not } \\
\text { exclude the possibility for these professionals take } \\
\text { over tasks, other than their own original jobs. }\end{array}$ \\
\hline
\end{tabular}

Table 1. Communication guide planning to librarians

Source: By authors

In the relationship with external public, for instance, the use of media and social media, which aim to reach people in general and attract the to the library is appropriate. For this study, we defined the administrative staff, the assistant librarian and reference librarian as adequate for executing the task, as they have contact with social media technologies.

The organization staff should work together with these professionals, as they are aware of the collection and may be able to choose strategic places to be worked. Finally, the standard and reference librarian, because they know the users' needs and desires, develop high impact innovations.

We note, therefore, that it is a matter of applying abilities and knowledge acquired at work. Separating or joining working efforts depends on the diagnosis perception that each professional has according to the objectives of the project.

Participation in events is another action to be developed by library institutions, as it is the moment attention is sharpened by the use of hybrid libraries. 
This action is in charge of the director and reference librarians, since they know the institution policies and the possible actions within them.

The involvement of all professionals of the institution is a premise in carrying out this project, as when one sector of the library stops, the others are influenced. Hence, when all the professionals work collaboratively for a specific end, with the users, service is offered in a structured and strategic way.

Finally, the relationship with the library staff refers to the relationship among the professionals working in the library environment. In this perspective, the distribution of tasks is a means of organization that does not exclude the possibility of acting in other activities that are not part of his/her daily job.

\section{Conclusion}

Reading converging languages is difficult to understand when visual language syntax is not properly studied and decoded. Thus, new forms of information perception provided by media converging in different support interfere in the process of creating meanings.

Starting with the basics, knowledge on visual language techniques may create an audience to better cope with visual manifestations. Visual literacy, therefore, parts from what we extract from our visual experience and how we do it, from the understanding that syntax determines language semantics.

Considering that human beings receive and express visual messages at representational, abstract and symbolic levels, the study of visual language syntax showed that the most important visual element in the process of human perception is the color tone. Secondly, the search for balance of non-balanced images, which varies according to the light.

Image treatment techniques change according to the author's intention. This way, if the goal is to achieve balance and leveling to human eyes, it is important to plan the measurements of visual interpretation with stabilization axes, i.e., vertical and horizontal axis.

However, if the intention is to create impact on viewers, we recommend the use of tension, contrast and sharpening (complex and exaggerated variation). Thus, the effort librarians make in disseminating visual languages is in applying forms of perceptions and methodologies that stimulates critical users in relation to the information they receive.

Human perception presupposes, in relation to visual decoding, the way image is seen or demonstrated. Therefore, by establishing policies for institutional service, the librarian must take into account the strategic plan to 
overcome barriers between users and librarians, whether physical (regarding the organization environment), psychological or bureaucratic.

In this context, hybrid libraries, by using hybrid spaces and multiple languages, allows greater interaction between professionals and users. These systems create relationships between humans and technologies, permeated by media and flexible languages, i.e., a mix of writing, sound and image.

This way, hybrid libraries break through consolidated parameters of seeing and understanding, interfering in knowledge construction and dissemination. The act of "seeing" is then more creative, resulting in articulation of languages in the exercise of interpreting contexts.

Therefore, understanding and using visual languages both in analog and digital media serve as attractive convergences to the eyes of those who experience it. At the same time, they contribute to digital inclusion, as the convergences of different languages and informational support provide access to technologies, at times inaccessible to a particular public.

Thus, in order to break through barriers between the readers and the items present in an information unit, as well as new technological media, it is necessary to create proximity between visual elements and information professionals. In this sense, one must consider that visual information is information means of great demand in our digital era, and that people interact with images at all times.

Thus, if at some point in our lives we will be in touch with these languages, we must be able to understand them. In this scenario, understanding that different meanings and information may comprehend one same object is essential for this process.

In this same line of thought, the change suffered by the environment through sensory stimulation techniques transforms the library into a living space, which facilitates the process of human perception. To this end, information professionals need to be able to deal with the dynamics proposed by the convergence of languages, media and people.

The environment of a hybrid library needs, therefore, to provide dynamic activities to attract different people, languages and technologies. The librarian, consequently, has the role of facilitating the process of learning languages, diversifying the quality of services and products offered by the institution.

Images, for being concise, conduct humans to think about the intrinsic meanings of what they see, as in our visual unconscious most things we read and hear are transformed into images by they our brain. Therefore, hybrid libraries, through the convergence of languages, created a greater demand for libraries, assigning an inclusive characteristic to who experience these environments. 


\section{REFERENCES}

Arnheim, Rudolf. 2005. Arte e percepção visual: uma psicologia da visão criadora. São Paulo: Pioneira Thomson Learning.

Benjamin, Walter. 2008. The work of art in the age of mechanical reproduction. Londres: Penguin Books.

Bernardino, Maria Cleide Rodrigues e Emir Jose Suaiden. 2011. "O papel social da biblioteca pública na interação entre informação e conhecimento no contexto da Ciência da Informação". Perspectivas em Ciência da Informação (outubro/dezembro). Belo Horizonte. <http://portaldeperiodicos.eci.ufmg.br/index.php/pci/article/view/1257/970>, consultado em 2 de fevereiro de 2016.

Bruce, Christine Susan. 2003. "Las siete caras de la alfabetización en información en la enseñanza superior". Anales de Documentación, no. 6: 289-294 (Universidad de Murcia, Espinardo, España). <http://www.redalyc.org/articulo.oa?id=63500619>, consultado em 18 de janeiro de 2016.

Caldas, Rosângela Formentini. 2013. "Análise da integração da tecnologia em instituições de ensino superior através da gestão do conhecimento: Projeto Unintera”. Lisboa: paper presented at the Congresso Internacional tic e Educação, November 30- December 2. <http://ticeduca.ie.ul.pt/atas/pdf/74.pdf>, consultado em 12 de dezembro de 2015.

Castells, Manuel. 2001. A sociedade em rede. São Paulo: Paz e Terra.

Crawford, Walt and Michael Gorman. 1995. Future libraries: Dreams, madness and reality. Chicago: American Library Association.

Dias de Macedo, Neusa. 1990. "Princípios e reflexões sobre o serviço de referência e informação”. Revista Brasileira de Biblioteconomia e Documentação 23 (1-4): 9-37 (janeiro/dezembro). São Paulo.

Dondis, Donis A. 2003. Sintaxe da linguagem visual. São Paulo: Martins Fontes.

International Federation of Library Associations and Institutions (IFLA). 2014. "Declaração de Lyon sobre o acesso à informação e desenvolvimento". <http:// www.lyondeclaration.org/content/pages/lyon-declaration-pt.pdf>, consultado em 11 de setembro de 2015.

Johannessen, Soren. "Um manifesto 2.0 do bibliotecário". Tradução: Maria José Vicentini Jorente. Youtube.com. https://www.youtube.com/watch?v=Yj1p0A8DMrE, consultada em 4 de outubro de 2015.

Joly, Martine. 2007. Introdução à análise da imagem. Lisboa: Editora 70.

Pereira dos Santos, Marcos. 2013. "A pedagogia filosófica do movimento iluminista no século xviii e suas repercussões na educação escolar contemporânea: uma abordagem histórica”. Imagens da Educação 3 (2): 1-13. <http://periodicos.uem. br/ojs/index.php/ImagensEduc/article/view/19881/pdf>, consultado em 5 de dezembro de 2015.

Pinfield, Stephen, Rosemary Russell, Jonathan Eaton, Astrid Wissenburg, Catherine Edwards and Peter Wynne. 1998. "Realizing the hybrid library". D-lib Magazine (october). Corporation for National Research Initiatives, United States. <http:// www.dlib.org/dlib/october98/10pinfield.html>, consultado em 5 de janeiro de 2016.

Prakasan, E.R., T. Swarna and Viajai Kumar. 2000. "Human resource development in hybrid libraries". Chennai, India: paper presented at the National Convention 
on Library and Information Networking, December 24-25. <http://eprints.rclis. org/5864/1/pdf.pdf>, consultado em 18 de dezembro de 2015.

Russel, Rosemary, Tracy Gardener and Paul Miller. 1999. "Hybrid information environments - overview and requirements". mia Requirements Analysis Study. $<$ http://www.ukoln.ac.uk/dlis/models/requirements/overview/>, consultado em 8 de novembro de 2015.

Santaella, Lúcia. 2001. Matrizes da linguagem visual e pensamento: sonora, visual, verbal. São Paulo: Iluminuras.

Simili, Ivana Guilherme. 2008. "Educação e produção de moda na segunda guerra mundial: as voluntárias da Legião Brasileira de Assistência”. Cadernos Pagu (julho/ dezembro). <http://www.scielo.br/pdf/cpa/n31/n31a19.pdf>, consultado em 2 de fevereiro de 2016.

Stuart Garcez, Eliane Maria e Gregório J. Varvakis Rados. 2002. "Biblioteca híbrida: um novo enfoque no suporte à educação a distância”. Ciência da Informação (maio/agosto). Brasília. <http://www.scielo.br/pdf/ci/v31n2/12907.pdf>, consultado em 16 de janeiro de 2016.

Taylor, Steven J., Robert Bogdan and Marjorie L. Devault. 2015. Introduction to qualitative research methods: A guidebook and resource. Hoboken, N.J.: John Wiley and Sons.

Para citar este texto:

Da Silva, Rafaela Carolina, Maria José Vicentini Jorente, Rosângela Formentini Caldas y Natalia Nakano. 2018. "Visual information for digital inclusion process in hybrid libraries and librarians' action”. Investigación Bibliotecológica: archivonomía, bibliotecología e información 32 (76): 79-96.

http://dx.doi.org/10.22201/iibi.24488321xe.2018.76.57978 